\title{
EFFECT OF GARLIC OIL ON SOME BIOCHEMICAL PARAMETERS IN RATS EXPOSED TO HYDROGEN PEROXIDE
}

\author{
AZiza Raof Hajt, Tarik Abdulgadir Abdal ${ }^{*}$, Balgees Ahmed Ali $^{* *}$ and Megdad S. Ahmed ${ }^{* * *}$. \\ *Dept. of Physiology, Anatomy, and Theriogenology, Collage Of Veterinary Medicine, University Of \\ Duhok, Kurdistan Region-Iraq. \\ ***ept. of Medicine And Surgery, Collage Of Veterinary Medicine, University Of Duhok, Kurdistan \\ Region-Iraq. \\ *** Duhok Research Centre, Collage Of Veterinary Medicine, University Of Duhok, Kurdistan Region-Iraq.
}

(Received: September 18, 2019; Accepted for Publication: November 28, 2019)

\begin{abstract}
Introduction: Medicinal plants have therapeutic impacts in both modern and traditional medicines. Therefore, some biochemical parameters were investigated in rats fed with garlic oil daily for three weeks. Methods: A total of 20 healthy adult Wister albino male rats aged eight weeks and older were allocated into four equal groups as follow. Group I or control treated with normal diet and water. Group II/ administrated by $1 \%$ hydrogen peroxide $\left(\mathrm{H}_{2} \mathrm{O}_{2}\right)$ with drinking water in a dark bottle prepared daily with normal diet. Group III administrated with $5 \mathrm{ml}$ garlic oil added to 25 grams of their ratio for each rat (25oil/125g) also prepared daily with normal drinking water. Group IV also administrated with $5 \mathrm{ml}$ of garlic oil added to 25 gram of their ratio with drinking water that contained $1 \%$ hydrogen peroxide in a dark bottle.

Results: The subjects in the garlic group had significantly lower total cholesterol $(54.30 \mathrm{vs} .68 .90 \mathrm{mg} / \mathrm{dl})$; VLDL (12.64 vs. $14.62 \mathrm{mg} / \mathrm{dl})$; LDL (32.27 vs. $46.75 \mathrm{mg} / \mathrm{dl})$; and higher HDL (9.39 vs. $7.53 \mathrm{mg} / \mathrm{dl})$ ) compared to the control group. The difference in liver and kidney parameters between the control and $\mathrm{H} 2 \mathrm{O} 2$ + garlic was not significant. Similarly, no significant difference was found between the garlic and control group in GPT (20.23 vs. 23.38$)$; urea (40.80 vs. 37.10$)$; uric acid $(0.53$ vs. 0.59$)$; and creatinine $(0.57$ vs. 0.78); except for GOT (15.80 vs. 30.04).

Conclusions: The present study showed the garlic extract is effective to reduce total cholesterol, LDL, VLDL, GOT and increase HDL levels.
\end{abstract}

KEYWORDS: lipid profile, liver parameters, garlic, antioxidant https://doi.org/10.26682/ajuod.2019.22.2.18

\section{INTRODUCTION}

$\mathbf{M}$ edicinal plants have valuable therapeutic impacts in both modern and traditional medicines. Garlic (Allium sativum) is being used as food, as well as it has been used as a medicinal plant for more than 4000 years for a wide range of purposes (Block, 1985). The garlic is being used in headache, treating bites, and in intestinal worms and tumors (Block, 1985; Amagase et al., 2001; Rahman et al., 2006). Garlic and its supplements are used as food in several cultures for their hypo-lipidemic, antiplatelet, and beneficial circulatory advantages. Also, it appears that garlic has the role of hepatoprotective, immune- enhancing, anticancer, chemopreventive, and antioxidant activities (Amagase et al., 2001; $\underline{\text { S. }}$ K. Banerjee et al., 2002).

While, the investigations conducted on garlic powder and garlic oil have failed to confirm its role as lipid-lowering or hypoglycemia effects (Kwon et al., 2003; Amagase, 2006). The findings from a meta-analysis showed that garlic is effective in decreasing total serum cholesterol by $17 \pm 6 \mathrm{mg} / \mathrm{dL}$ and low-density lipoprotein cholesterol by $9 \pm 6 \mathrm{mg} / \mathrm{dL}$ in subjects with elevated total cholesterol levels (>200 mg/dL) in the case of using garlic for 2 months (Ried et al., 2013).

Lee et al. (2009) examined the antioxidant effect of garlic in an animal model of type 2 
diabetes mellitus. In this regard, they measured the antioxidant activity of garlic and aged black garlic as the activity in scavenging free radicals. The three-week-old mice were fed AIN-93G diet or diet containing $5 \%$ freeze-dried garlic or aged black garlic for seven weeks. The antioxidant activity of garlic and aged black garlic were 13.3 \pm 0.5 and $59.2 \pm 0.8 \mu \mathrm{mol} / \mathrm{g}$ wet weight, respectively. Moreover, they found that aged black garlic consumption reduced the hepatic thiobarbituric acid reactive substances (TBARS) level in a significant way compared to the garlic group. Other studies have reported similar findings on the effect of garlic on the antioxidant level. For example, S. Baneriee et al. (2003) reviewed the current evidence on the effect of garlic on the antioxidant level and showed that garlic has a significant effect on the antioxidative effect.

Eidi et al. (2006) investigated the antidiabetic effect of garlic ethanolic extract in normal and streptozotocin-induced diabetic rats. They fed the rats with oral administration of garlic extract $(0.1,0.25$ and $0.5 \mathrm{~g} / \mathrm{kg}$ body wt.) for two weeks. They found that oral administration of the garlic extract substantially reduced the serum glucose, total cholesterol, triglycerides, uric acid, creatinine, AST (GOT) and ALT (GPT) and urea levels. Importantly, the study found that the antidiabetic effect of the extract was more effective than that observed withglibenclamide. However, still, there are not sufficient clinical trials on the impact of garlic extraction on the antioxidative impact on animals to make a conclusive decision.

This study aimed to examine the effectiveness of garlic extraction on some biochemical parameters in rats fed with garlic oil daily for three weeks.

\section{MATERIALS AND METHODS}

In this experimental study, a total of 20 healthy male adult rats were assigned into three experimental groups along with its control group. The lipid profile parameters, including triglyceride (TG), high density lipoprotein (HDL), and total cholesterol (T-CH) along with some liver and kidney function indicators including GOT, GPT, uric acid, urea, alkaline phosphatase. Creatinine was measured two times, once after 30 seconds and another time after 2 minutes in three groups. These parameters were compared with those in the control group.

The study was conducted at the Department of Physiology, College of Veterinary Medicine in Duhok city from period March 2018 to May 2018.

\section{EXPERIMENTAL GROUPS}

A total of 20 healthy adult Wistar albino male rats aged more than 8 weeks weighted $250 \pm 10$ $\mathrm{gm}$ were allocated into four equal groups as follow. Group I or control treated with normal diet and water. Group II/ administrated by $1 \%$ hydrogen peroxide $(\mathrm{H} 2 \mathrm{O} 2)$ with drinking water in a dark bottle prepared daily. Group III treated with $5 \mathrm{ml}$ of garlic oil. The garlic oil was added to 25 grams of this ratio for each rat along with normal drinking water. Finally, group IV was administered with $5 \mathrm{ml}$ of garlic oil that was added to 25 grams of their ratio together with drinking water along with $1 \%$ hydrogen peroxide in a dark bottle.

The rats were in the light/dark cycle for one week prior to study commencement. The healthy rats were purchased from the College of Science, University of Duhok.

\section{GARLIC EXTRACTION TECHNIQUE}

To prepare garlic extract, the fresh garlic bulbs were obtained from retail local food store. The garlic bulbs cut by a sharp knife into small pieces then were weighed and blended by an electrical grinder ,one litter of ethanol $70 \%$ was added to each $1000 \mathrm{~g}$ of garlic extract, it was kept at room temperature for $48 \mathrm{~h}$ and then sieved by gauze. The alcoholic garlic mixture was collected in a flask and concentrated in die rotary flash evaporator Sushama et al.,(2012) The amount of garlic oil about 3-10 ml of were prepared for feeding the rats

\section{BLOOD COLLECTION AND MEASUREMENT}

Blood samples $(5 \mathrm{ml})$ were taken from the subjects through the retro-orbital venous plexus and were entered to non-heparinized tubes after 21 days of the study the blood samples were collected to measure the biochemical parameters following fasting 12-16 hours. The serum 
samples were centrifuged at $3500 \mathrm{rpm}$ using cooling centrifuge at $4 c^{\circ}$ for 10 minutes. Accordingly, the separated sera were stored at $28 \mathrm{C}^{\circ}$ to estimate biochemical parameters. To assess liver, kidney, and lipid profile levels in subjects, the specific enzymatic kit was used using spectrophotometer according to the Biorex diagnostics. The lipid profile parameters included cholesterol ( $\mathrm{T}-\mathrm{CH} \mathrm{mg} / \mathrm{dL}$ ), highdensity lipoprotein (HDL $\mathrm{mg} / \mathrm{dL}$ ), and triglyceride (TG $\mathrm{mg} / \mathrm{dL}$ ) were measured, using Biolab Kit (Germany). The liver and kidney functions which were measured included GOT, GPT, urea, uric acid (UA), and creatinine following 30 minutes and 2 minutes.

\section{STATISTICAL METHODS}

The normality of the lipid profiles and kidney parameters among study groups was tested using drawing a histogram. The descriptive purposes of the study were presented in mean and standard deviation. The lipid profile parameters, liver, and kidney functions were compared between control and $\mathrm{H}_{2} \mathrm{O}_{2}$, garlic, and $\mathrm{H}_{2} \mathrm{O}_{2}+$ garlicgroups was examined in independent t-test. The P-value of less than 0.05 was considered a significant difference. The statistical calculations were performed by Statistical Package for Social Sciences 24 (SPSS 24; IBM; USA).

\section{RESULTS}

The comparison of lipid profile parameters between the subjects in the control and other groups was presented in Table 1 . The study showed that the subjects in $\mathrm{H} 2 \mathrm{O} 2$ group had significantly $(\mathrm{P}<0.01)$ worse level of lipid profile compared to the subjects in the control group; including TG (146.79 vs. $73.09 \mathrm{mg} / \mathrm{dl})$; total cholesterol (123.60 vs. $68.90 \mathrm{mg} / \mathrm{dl})$; HDL (5.79 vs. $7.53 \mathrm{mg} / \mathrm{dl})$; VLDL (29.36 vs. $14.62 \mathrm{mg} / \mathrm{dl})$; and LDL (88.45 vs. $46.75 \mathrm{mg} / \mathrm{dl}$ ). However, no significant difference was seen in the lipid parameters between the control and $\mathrm{H} 2 \mathrm{O} 2+$ garlic group (Table 1).

The subjects in the garlic group had significantly lower concentration total cholesterol (54.30 vs. $68.90 \mathrm{mg} / \mathrm{dl})$; VLDL (12.64 vs. $14.62 \mathrm{mg} / \mathrm{dl})$; and LDL (32.27 vs. $46.75 \mathrm{mg} / \mathrm{dl})$; and higher concentration of HDL ( 9.39 vs. $7.53 \mathrm{mg} / \mathrm{dl}$ ) compared to control group, respectively. But, there was no statistically significant difference in the TG (63.21 vs. 73.09; $\mathrm{P}>0.05$ ), respectively as shown in Table 1 .

Table (1): Comparison of lipid profile parameters between control and $\mathrm{H}_{2} \mathrm{O}_{2}$, garlic, and $\mathrm{H}_{2} \mathrm{O}_{2}+$ garlicgroups

\begin{tabular}{lccccc}
\hline Study Groups & $\begin{array}{c}\text { Triglyceride } \\
(\mathbf{m g} / \mathbf{d L})\end{array}$ & $\begin{array}{c}\text { Cholesterol } \\
(\mathbf{m g} / \mathbf{d L})\end{array}$ & $\begin{array}{c}\text { LDL } \\
(\mathbf{m g} / \mathbf{d L})\end{array}$ & $\begin{array}{c}\text { VLDL } \\
(\mathbf{m g} / \mathbf{d L})\end{array}$ & $\begin{array}{c}\text { LDL } \\
(\mathbf{m g} / \mathbf{d L})\end{array}$ \\
\hline $\mathrm{Control}$ & $73.09 \pm 12.74$ & $68.90 \pm 6.80$ & $7.53 \pm 0.39$ & $14.62 \pm 2.55$ & $46.75 \pm 6.28$ \\
\hline $\mathrm{H}_{2} \mathrm{O}_{2}$ & $146.79 \pm 5.81^{*}$ & $123.60 \pm 17.34^{*}$ & $5.79 \pm 0.48^{*}$ & $29.36 \pm 1.16^{*}$ & $88.45 \pm 18.16^{*}$ \\
\hline $\mathrm{Garlic}$ & $63.21 \pm 2.28$ & $54.30 \pm 3.37^{*}$ & $9.39 \pm 0.54^{*}$ & $12.64 \pm 0.46$ & $32.27 \pm 3.74^{*}$ \\
\hline $\mathrm{H}_{2} \mathrm{O}_{2}+$ garlic & $73.93 \pm 2.64$ & $67.80 \pm 10.25$ & $18.69 \pm 14.70$ & $14.79 \pm 0.53$ & $34.32 \pm 23.67$ \\
\hline $\begin{array}{l}\text { Independent t-test was performed for all statistical analysis. } \\
\begin{array}{l}\text { Point: } \\
\text { asterisk. }\end{array}\end{array}$ & & & & \\
\hline
\end{tabular}

The study showed that the subjects included in the $\mathrm{H} 2 \mathrm{O} 2$ group had significantly higher concentrations of GOT (76.64 vs. 30.04); GPT (64.94 vs. 23.38); Urea (59.68 vs. 37.10$)$; uric acid (0.92 vs. 0.59$)$; but no difference in creatinine (1.26 vs. 0.78) compared to the subjects in control group (table 2)
Whereas, the difference in liver and kidney parameters between the control and $\mathrm{H} 2 \mathrm{O} 2+$ garlic was not significant. Similarly, no significant difference was found between the garlic and control group in GPT (20.23 vs. 23.38 ); urea ( 40.80 vs. 37.10$)$; uric acid ( 0.53 vs. $0.59)$; and creatinine (0.57 vs. 0.78$)$; except for GOT (15.80 vs. 30.04), as shown in Table 2. 
Table (2): Comparison of kidney and liver function parameters between control and $\mathrm{H}_{2} \mathrm{O}_{2}$, garlic, and $\mathrm{H}_{2} \mathrm{O}_{2}$ +garlic study groups

\begin{tabular}{lccccc}
\hline Study Groups & GOT (U/L) & GPT (U/L) & $\begin{array}{c}\text { Liver and Kidney Parameters } \\
(\mathbf{m g} / \mathbf{d l})\end{array}$ & $\begin{array}{c}\text { Uric Acid } \\
(\mathbf{m g} / \mathbf{d l})\end{array}$ & $\begin{array}{c}\text { Creatinine } \\
(\mathbf{m g} / \mathbf{d l})\end{array}$ \\
\hline Control & $30.04 \pm 3.46$ & $23.38 \pm 11.09$ & $37.10 \pm 8.39$ & $0.59 \pm 0.05$ & $0.78 \pm 0.26$ \\
\hline $\mathrm{H}_{2} \mathrm{O}_{2}$ & $76.64 \pm 9.19^{*}$ & $64.94 \pm 10.53^{*}$ & $59.68 \pm 1.30^{*}$ & $0.92 \pm 0.07^{*}$ & $1.26 \pm 0.49$ \\
\hline Garlic & $15.80 \pm 1.44^{*}$ & $20.23 \pm 6.98$ & $40.80 \pm 9.84$ & $0.53 \pm 0.01$ & $0.57 \pm 0.15$ \\
\hline $\mathrm{H}_{2} \mathrm{O}_{2}+$ garlic & $29.60 \pm 5.30$ & $30.73 \pm 6.29$ & $34.10 \pm 4.06$ & $0.58 \pm 0.03$ & $0.68 \pm 0.34$ \\
\hline
\end{tabular}

Independent t-test was performed for all statistical analysis.

Point: *Significant at 0.01 level.The non-significant difference between control and other groups was not presented by an asterisk.

\section{DISCUSSION}

The present interventional investigation showed that the subjects in the garlic group had significantly lower concentration of total cholesterol, LDL, VLDL, and higher concentration of HDL compared to the subjects included in the control group.

Also, it was shown that the garlic extraction is effective to reduce the level of GOT compared to the control. However, it has an antioxidant effect on the subjects underwent $\mathrm{H} 2 \mathrm{O} 2$.

The effect of garlic extraction on lipid profile and biochemical parameters have been investigated by other studies as well. For example, $\mathrm{Ha}$ et al. (2015)included thirty-two male Sprague-Dawley rats aged four weeks into four groups in a random way. The rats were fed for five weeks. The groups were fed with normal food diet; a high-fat diet; a high-fat diet along with $0.5 \%$ black garlic extract; and a high-fat diet along with $1.5 \%$ black garlic extract (HFBG1.5). The authors measured body weight, biochemical parameters, and expression of genes associated with lipid metabolism. The study showed that the subjects who were included in the HFBG1.5 had significantly lower concentrations of blood biochemical parameters compared to those included in the high-fat group. In addition, the significant improvements were observed in the plasma lipid profiles as well as fecal excretions of total lipid and triglyceride in the HFBG1.5 group compared to the high-fat diet group. The HFBG1.5 group had significantly lower body weight and weight gain compared to other groups.

The levels of AST in the high-fat group were substantially elevated in contrast with a lower level in the HFBG1.5 group. Similarly, the subjects in both HFBG0.5 and HFBG1.5 groups had significantly lower levels of ALT (Ha et al., 2015). The similar results were reported by other studies as well (Yeh et al., 2001; Jang et al., 2008).

The studies conducted on the effect of garlic powder or oil were not successful to show any lipid-lowering or hypoglycemia effects (Kwon et al., 2003; Amagase, 2006).

The lipid-lowering role of garlic extract is so important, as the excessive fat intake changes the lipid metabolism and expose the persons to the various diseases; such as fatty liver disease, hypertension, hyperlipidemia, and arteriosclerosis (Larsson, 2013). The effects of garlic extract on lipid profile parameters have been supported by other studies as well ( $\underline{\text { Lin et }}$ al., 2002; Jung et al., 2011). The amount of the garlic supplements were given to the animals were different among investigations; including 3-5\% fresh garlic or black garlic extract (Seo et al., 2009; Jung et al., 2011), while 3-5T garlic in the rat's diet was so high elsewhere (Gardner et al., 2001).

The changes in the AST and ALT as serum biomarkers of liver change are observed in highfat diets (Shin et al., 2014). The effects of the intake of $0.2-1.0 \%$ fresh garlic extract for a short period on AST and ALT lowering have been reported in repeatedly in the literature (Chen et al., 1999; Yeh et al., 2001; Jo et al., 2002).

\section{STRENGTHS AND LIMITATIONS}

The strong point of the study may back to the number of groups who were included in the study. However, the findings reported in this study may not be consistent with some 
investigations due to discrepancies in the types of garlic studies, included raw garlic, cooked garlic, or black garlic.

\section{Conclusions and recommendations}

The present study showed the garlic extract could play a lipid-lowering role and antioxidant against $\mathrm{H} 2 \mathrm{O} 2$ and reducing the level of GOT.

Acknowledgment: the authors would like to present their deep thanks to Mohammed Saleem Mohammed,Megdad S. Ahmed for their kind assistance.

\section{REFERENCES}

Amagase, H. Clarifying the real bioactive constituents of garlic. The Journal of nutrition. 2006; 136(3): 716S-725S

Amagase, H, Petesch, BL, Matsuura, H, Kasuga, S, \& Itakura, Y. Intake of garlic and its bioactive components. The Journal of nutrition. 2001; 131(3): 955S-962S

Banerjee, S, Mukherjee, PK, \& Maulik, S. Garlic as an antioxidant: the good, the bad and the ugly. Phytotherapy Research: An International Journal Devoted to Pharmacological and Toxicological Evaluation of Natural Product Derivatives. 2003; 17(2): 97-106

Banerjee, SK, \& Maulik, SK. Effect of garlic on cardiovascular disorders: a review. Nutrition journal. 2002; 1(1): 4

Block, E. The chemistry of garlic and onions. Sci Am. 1985; 252(3): 114-119

Chen, L, Hong, JY, So, E, Hussin, AH, Cheng, WF, \& Yang, CS. Decrease of hepatic catalase level by treatment with diallyl sulfide and garlic homogenates in rats and mice. Journal of biochemical and molecular toxicology. 1999; 13(3- 4): 127-134

Eidi, A, Eidi, M, \& Esmaeili, E. Antidiabetic effect of garlic (Allium sativum L.) in normal and streptozotocin-induced diabetic rats. Phytomedicine. 2006; 13(910): $624-629$

Gardner, CD, Chatterjee, LM, \& Carlson, JJ. The effect of a garlic preparation on plasma lipid levels in moderately hypercholesterolemic adults. Atherosclerosis. 2001; 154(1): 213-220

Ha, AW, Ying, T, \& Kim, WK. The effects of black garlic (Allium satvium) extracts on lipid metabolism in rats fed a high fat diet. Nutrition research and practice. 2015; 9(1): 30-36

Jang, E-K, Seo, J-H, \& Lee, S-P. Physiological activity and antioxidative effects of aged black garlic (Allium sativum L.) extract. Korean Journal of Food Science and Technology. 2008; 40(4): 443-448

Jo, H, \& Choi, M. Effect of $1 \%$ garlic powder on serum and liver lipid and plasma amino acid concentration in rats fed cholesterol diet. JOURNAL-KOREAN SOCIETY OF FOOD SCIENCE AND NUTRITION. 2002; 31(1): 98-103

Jung, Y-M, Lee, S-H, Lee, D-S, You, M-J, Chung, IK, Cheon, WH, et al. Fermented garlic protects diabetic, obese mice when fed a high-fat diet by antioxidant effects. Nutrition research. 2011; 31(5): 387-396

Kwon, M-J, Song, Y-S, Choi, M-S, Park, S-J, Jeong, K-S, \& Song, Y-O. Cholesteryl ester transfer protein activity and atherogenic parameters in rabbits supplemented with cholesterol and garlic powder. Life sciences. 2003; 72(26): 2953-2964

Larsson, SC. Dietary fats and other nutrients on stroke. Current opinion in lipidology. 2013; 24(1): 41-48

Lee, Y-M, Gweon, O-C, Seo, Y-J, Im, J, Kang, M-J, Kim, M-J, et al. Antioxidant effect of 
garlic and aged black garlic in animal model of type 2 diabetes mellitus. Nutrition research and practice. 2009; 3(2): 156-161

Lin, MC, Wang, E-J, Lee, C, Chin, K, Liu, D, Chiu, J-F, et al. Garlic inhibits microsomal triglyceride transfer protein gene expression in human liver and intestinal cell lines and in rat intestine. The Journal of nutrition. 2002; 132(6): 1165-1168

Rahman, K, \& Lowe, GM. Garlic and cardiovascular disease: a critical review. The Journal of nutrition. 2006; 136(3): 736S-740S

Ried, K, Toben, C, \& Fakler, P. Effect of garlic on serum lipids: an updated meta-analysis. Nutrition reviews. 2013; 71(5): 282-299

Seo, Y-J, Gweon, O-C, Im, J, Lee, Y-M, Kang, M-J, \& Kim, J-I. Effect of garlic and aged black garlic on hyperglycemia and dyslipidemia in animal model of type 2 diabetes mellitus. J Food Sci Nutr. 2009; 14(1): 1-7

Shin, JH, Lee, CW, Oh, SJ, Yun, J, Kang, MR, Han, S-B, et al. Hepatoprotective effect of aged black garlic extract in rodents. Toxicological research. 2014; 30(1): 49

Sushama,M. ; Eswarudu, M.M. ; Venkateshwaralu, and Radhika,P.(2012) Evaluation of anti epileptic activity of Pisidium Guajana leaves extract in mise I nt.J of research of pharma and Biom.Sci, 3(2): 887-886

Yeh, Y-Y, \& Liu, L. Cholesterol-lowering effect of garlic extracts and organosulfur compounds: human and animal studies. The journal of nutrition. 2001; 131(3): 989S-993S

\section{تاثير زيت الثوم في بعض القيم الكيموحيوية في الفئران المعرضة لبيروكسيد الهيدروجين.}




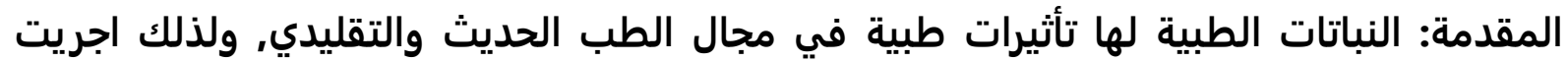

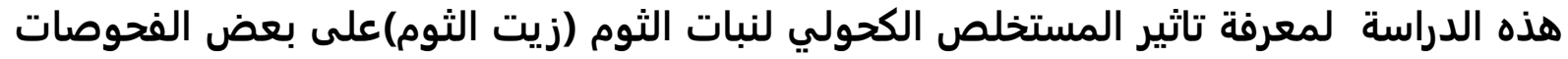

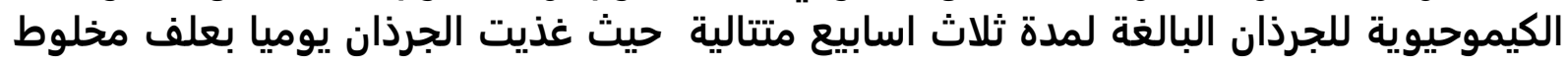
بزيت الثوم المواد وطرق الثوم البحث: اجريت الدراسة على 20 من ذكورالجرذان البالغة من صنف وئف ويستر البينو

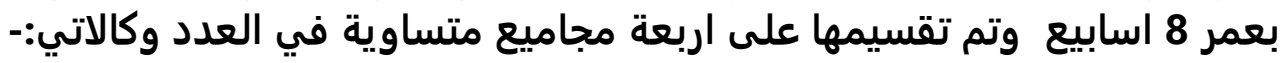

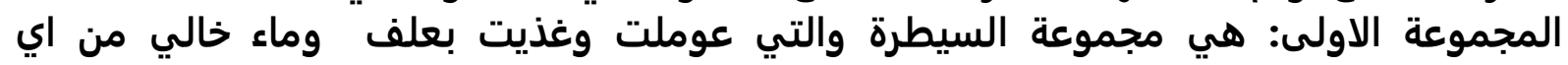
اضافة. المجموعة الثانية: عوملت الجرذان ب1\% 1افة من بيروكيد الهيدروجين المخفف بالماء والمحضر يوميا +علف خالي من اي اضافة.

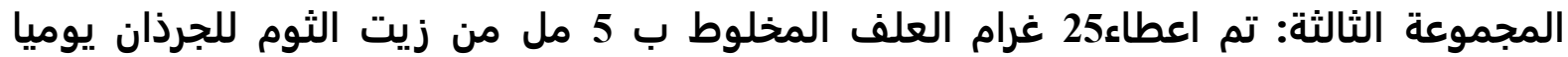

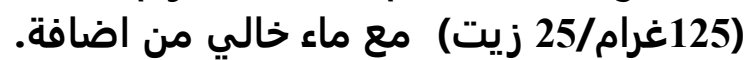

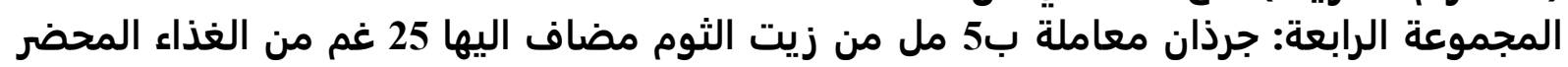

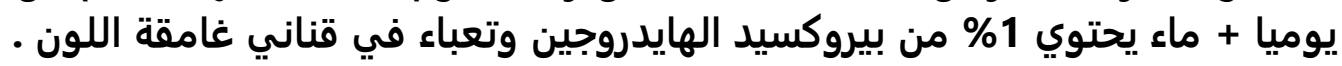

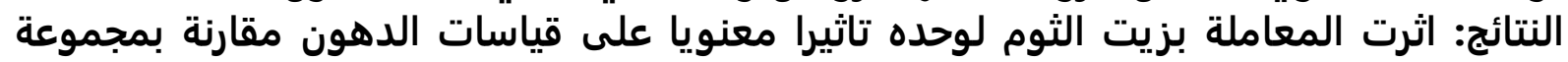
السيطرة على مستوى كل من الكوليسترول الكلي

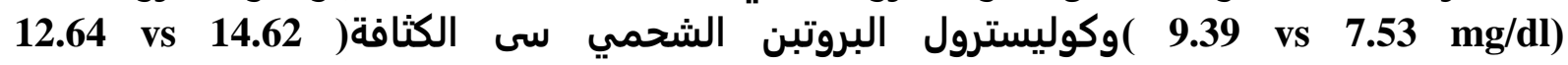

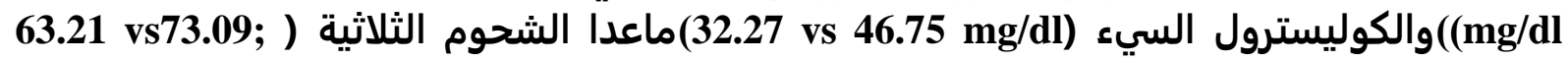

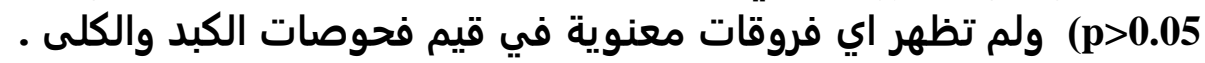

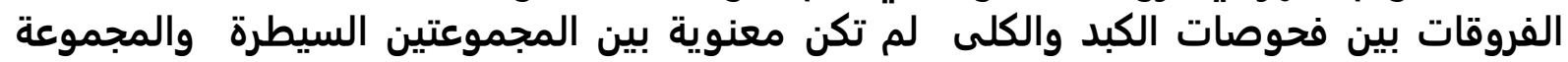
الرابعة وكذلك لم تكن هناك فروقات فيدات معنوية للمجموعتيين السابق ذكرهما في

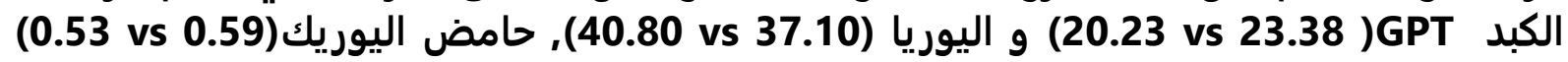
وبالاضافة الى قيم الكرياتنيين (15s 0.78 vs 0.57 ) ما عدا قيم انزيم ناقلة امين الاسبارتات • 15.80 vs 30.04 الاستنتاجات:- اظهرت الداته الدراسة الحالية ان مستخلص الثوم كان له دور في خفض مستوى

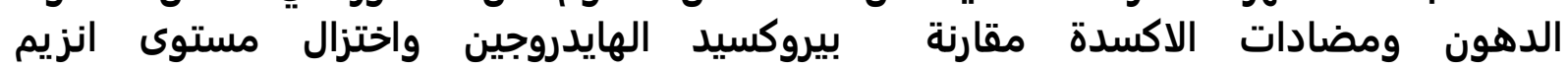
الكبد)GOT(AST. الكلمات الدالة: فحص الدهون, فحص انزيمات الكبد, الثوم: مضادات الاكسدة. 